\title{
THE ALTERNATIVE NET MODEL WITH THE FUZZY DECISION NODE FOR THE CONSTRUCTION PROJECTS PLANNING
}

\begin{abstract}
N. IBADOV ${ }^{1}$
The new approach to the construction project planning is presented in the article. The classical net model is enriched by the fuzzy decision node. The decision node allows for alternate choices dependent on appearing circumstances. The alternative net model with fuzzy decision node is an acyclic multi-graph, where some, chosen nodes (events) have multiple connections. These connections represent alternative methods of the certain work execution. Every work (activity) $(i, j)$ in the net model with alternative methods of work execution, despite the basic information comprising the execution time, the cost, the number of necessary workers, should comprise additional information e.g. about a complexity of works, a real feasibility. The alternative ways of a given work execution are evaluated in the decision node based on the fuzzy decision model. Each method is evaluated by assigning it the preference level in a form of the value of the membership function - „equal or higher" $\mu_{\geq}$. The most preferable way of the work execution in a given circumstances, will have the highest value of preference level. When the choice is done the net model is solved in the traditional way. Therefore, the paper concentrates on the process of choosing the method of work execution in the fuzzy decision node. The example calculations accompanying the process of decision taking are presented too. The model requires the use of linguistic variables, a fuzzy numbers, as well as fuzzy preference relations together with some calculations applied the probability theory.
\end{abstract}

Key words: construction project planning, fuzzy decision node, net model analysis, linguistic variables, fuzzy numbers, fuzzy preference relation

\section{INTRODUCTION}

Within the management of the construction project the process of planning it is one of the most important elements influencing the possibility of keeping cost and time i.e. success of a project. It means that decisions taken during the planning phase have a fundamental meaning for construction

${ }^{1}$ PhD., Eng., Warsaw University of Technology, Faculty of Civil Engineering, Al. Armii Ludowej 16, 00-637 Warsaw, Poland, e-mail: n.ibadov@il.pw.edu.pl 
phase of a project. The main aim of planning of a construction projects is creating a reliable model of execution of the project. It is necessary for proper coordination of the building process participants' activities. The created model sets a sequence of execution of all works (activities). The process of planning starts before the final scope of works is set, and lasts even till the end of the project. Every stage of a project requires the planning activity with its characteristic methods and tools. The first stage of construction project planning is making preliminary plans - the basis of the project budget, determination of financial and non-financial necessary resources, organization of the project execution etc. Setting the levels of planning, the objects of planning are preceded for each specific project and it is determined taking into consideration following factors:

- specific character of the planned object,

- size of the planned object,

- geographical location of the planned object,

- other circumstances accompanying the works execution,

- time planned for project execution.

During this process, the number of levels of planning is set, relevant to the stages of the project as well as relationships (quantitative and time relations) between the planned activities. In a real construction project planning process negative phenomena - that can occur during execution stage and disturb it [2] - are taken into consideration. In general, the possibility of occurring these unfavorable circumstances (for construction project execution) and their negative consequences is named as the risk. It is widely known, that the factors influencing the risk has a random character, so they can be described with the use of term of probability theory, contrary to the "uncertainty" which cannot be described with numbers. In this approach, it is assumed that the probability distributions of the factors influencing the risk are known. Nevertheless finding the probability distribution of any hypothetic event, in a real, single construction project it is very difficult. For these reasons, occupancy of any risk factor is uncertain [6-7], [11], [14-16], [18-21]. The assumption made by the decision maker (the manager) about the probability distribution should make him aware of the negative effects of the divergence between assumptions made and the real circumstances. That is why, for the proper planning decision the suitable tool should be develop to model the uncertainty. This kind of model should allow for analysis of alternate variants of the whole project or its crucial parts, allowing for the proper choice of the variant in relation to the circumstances occurred. This is a multi-criteria decision making widely analyzed e.g. in [4-5], [8-10], [13], [20].

As a result of the process of planning the construction project the net model and the time schedule are created. It is to emphasize that the use of traditional methods (CPM and PERT) in construction 
industry, where projects are really complex, does not allow for analysis of alternate technologies or organizational solutions of all works necessary to execute.

Considering the fact, that managing the project is proceeded in non-stochastic uncertainty, it is hereby proposed creating - based on traditional net models - the alternate net model with a fuzzy decision node. This approach will allow to model alternative ways of executing a part of a project. The project manager, even surprised by unfavorable circumstances, having the alternatives (shown by fuzzy decision nodes) can adjust execution of the project to the circumstances occurred.

\section{ALTERNATIVE NET MODEL WITH A FUZZY DECISION NODE THE CORE AND THE METHODOLOGY}

The net model of a construction project can be created with a different topology and structure. Instead of creating different net models and choosing from them one, the best suitable for predicted circumstances, the alternative model with fuzzy decision node can be created, where the execution can be adopted to the circumstances appeared.

The alternative model with fuzzy decision node it is acyclic multi-graph, where connections (arrows) between some nodes are multiple ones. This multi-arrow structure represents alternate methods of executing a given activity. The preference level described by the values of membership functions of linguistic variables is compared to the important project indicators, based on fuzzy decision model in a decision node.

Every activity $(i, j), i=1, \ldots, n-1, j=2, \ldots, n, i<j$, in the net model despite basic features as: the time, the cost, the number of necessary workers can comprise information about technological complexity, real workability etc. As a result of evaluation every activity has assigned the degree of preference in a form of the value of membership function "equal or higher" $\mu_{\geq}$. The most preferred activity will have the highest degree of preference.

Let's analyze the net model - AOA type (activity on arrow). The concept of the alternative net model with the fuzzy decision node (compared to the traditional AOA net model) is shown on fig. 1. 


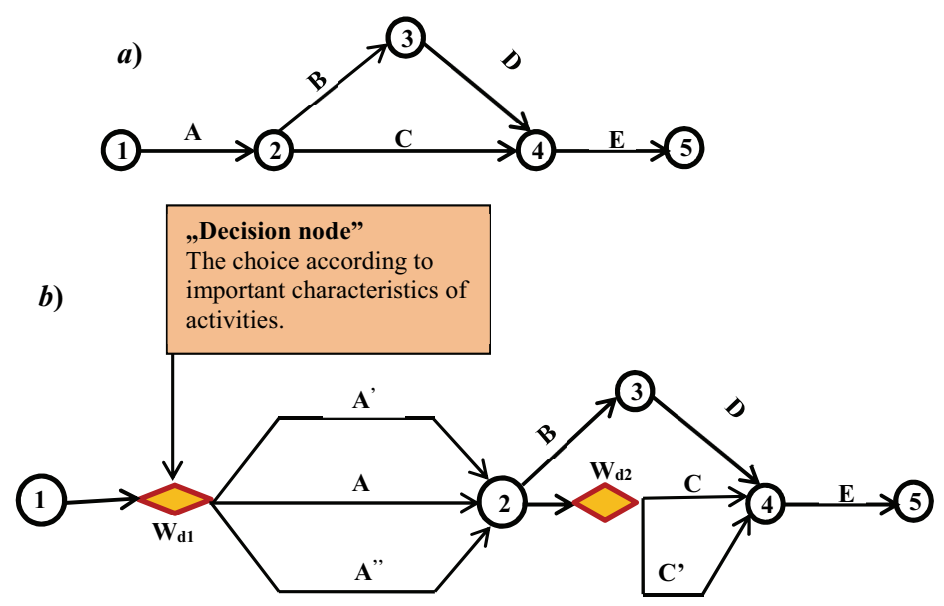

Fig. 1. The concept of a net model: a) AOA model; b) AOA model with the fuzzy decision nodes

Let $G=\left(X, A, S, W_{d}\right)$ be an acyclic multi-graph creating an alternate net model. It has a set of events $X=\{1,2, \ldots, k\}$ called nodes in net models, the set of directed arrows modelling all alternate variants $A=\left\{a_{1}, \ldots, a_{i}, \ldots, a_{n}\right\}$ (in the case shown in fig. 1 it will be a set of all of $\mathrm{A}$ and $\mathrm{C}$ alternatives), the set of directed arrows representing every work (activity) $S=\left\{s_{1}, \ldots, s_{i}, \ldots, s_{u}\right\}$ and the set of the decision nodes $W_{d}=\{1,2, \ldots m\}$ allowing for chosing the most prefarable variant of works based on a given decision model. It is to emphasise, that if there is only one variant of the work execution, then the decision node is cancelled. The preference level $\mu_{\geq}(i, j) \in[0,1]$ of the work $(i, j)$ having $r$ alternatives is based on criteria describing the preference of a given variant. The existance of the decision node means the necessity of the choice of the one from the variants represented by the arrows coming out of the decision node. When the decisions are made, the net model can be solved with a traditional method, as CPM is. The example of calculating the traditional net model with CPM method can be found in [17].

Introducing the decision nodes to the net model is justified by the fact, that costruction project planners regularly face the task of analyzing and selecting solutions in conditions of uncertainty caused by incomplete or unprecise input data. This is the main reason for introducing the planistic decision support system helping the specialists in proving their choices of technological, organizational, financial solution in the planned projects. Local, specific circumstances can be considered in their decisions too. The classical net model does not provide the possibility of analyzing 
alternate solutions and their final effect. The information about the level of preference $\mu_{\geq}$on a certain ways (activities) creates additional database helpful in case of excluding certain solution. This kind of database is not limited to initially inputted values. The change of circumstances of the project execution can make other criteria (than initially chosen) more important or even other project features influencing the execution more than it was initially thought. The changes and add-ins to the database can be made. The next important element of the methodology is fuzzy evaluation of analyzed alternatives with the use of linguistic variables as "better", "worse", "big", "small" etc. This approach allows for the formalization of initial data and the way of the decision taking. The alternatives are compared by creation of the series of ascending preferences (represented by certain numbers). On the initial phase of planning process, in most cases, initial input data are not precise and have a fuzzy nature, so using qualitative, expressed by natural language evaluations is justified and desired. The lack of precision of initial data arises from mistakes made during observation of processes, from lack of knowledge about important parameters of the project or circumstances accompanying its execution. This kind of uncertainty can be formalized mainly by using the natural language [24-25]. The possibility of analysis and calculation making depends directly on the choice of the mathematical tool. The fuzzy set theory invented by L.A. Zadeh [26] seems a very good, suitable choice, as it is successfully applied in modelling variety of processes in the construction industry [1], [6-8], [12], [20-23]. Considering the type of the input data, modelling linguistic variables with fuzzy numbers according to the author's opinion - is justified.

The mathematical basis of the choice made from alternatives in the net model is a fuzzy relation of ordering based on linguistic evaluations together with calculation methods applied in the probability theory. There is a lot of articles concerning the fuzzy relations, where the definitions, and classifications of fuzzy relations can be found [3], [5], [9-11], [27].

Let the alternatives in the net model are characterized by linguistic evaluations related to the evaluation criteria. The character of these evaluations is qualitative (in the relevant scales for the qualitative and quantitative properties) and is expressed by a fuzzy numbers. Let $A=$ $\left\{a_{1}, \ldots, a_{i}, \ldots, a_{n}\right\}$ be the set of alternate works; $X=\left\{x_{1}, \ldots, x_{i}, \ldots, x_{n}\right\}-$ the set of the values, where $x_{i}$ corresponds with the alternative $a_{i}$, where $i=1, \ldots, n ; K\left(x_{i}\right)=\left(K_{1}\left(x_{i}\right), \ldots, K_{r}\left(x_{i}\right), \ldots, K_{m}\left(x_{i}\right)\right)$ - vector, linguistic evaluation of $x_{i} ; K_{r}\left(x_{i}\right)$ - vector, linguistic evaluation of the $x_{i}$ value according to $r$ criterion where $r=1, \ldots, m$.

The fuzzy order relation for the fuzzy evaluation is determined through probabilistic evaluations made for their crisp (not fuzzy) equivalents [3]. Let introduce the fuzzy order relation type "equal-or- 
higher" $(\geq)$ in the set of linguistic evaluations $\boldsymbol{K}=\left(K\left(x_{1}\right), \ldots, K\left(x_{i}\right), \ldots, K\left(x_{n}\right)\right)$. The membership function of the fuzzy order will be as $\mu_{\geq}: \mathbf{K} \times \mathbf{X} \rightarrow[0,1]$. Let $\mu_{\geqq}: \mathbf{K} \times \mathbf{X} \rightarrow[0,1]$ be marked as $\mu_{\geq}^{r}\left(x_{i}, x_{j}\right)$. The value of this function for fuzzy numbers $K_{r}\left(x_{i}\right)$ i $K_{r}\left(x_{j}\right)$ can be calculated with the use of the formula (2.1).

$$
\mu_{\geq}(A, B)=1-\mu_{<}(A, B)
$$

where

A and B - fuzzy numbers

$\mu_{<}-$fuzzy order relation type „lower” in the fuzzy number set.

The level of the truthfulness $\mu_{<}(A, B)$ of the fuzzy expression $(A<B)$ is defeined as the probability that the crisp value of the fuzzy number $A$ is lower than the crisp value of the fuzzy number $B$ [3]:

$$
\mu_{<}(\mathrm{A}, \mathrm{B})=\mathrm{P}(\mathrm{nf}(\mathrm{A})<n f(B))
$$

where

$n f(A)$ - the crisp value of the fuzzy number A.

It implies:

$$
\mu_{<}(\mathrm{A}, \mathrm{B})=\sum_{\mathrm{i}=1}^{\mathrm{n}-1} \mathrm{P}\left(\mathrm{nf}(\mathrm{A})=\mathrm{y}_{\mathrm{i}} \& n f(\mathrm{~B})>\mathrm{y}_{\mathrm{i}}\right)
$$

Assuming the independence random variables based on the fuzzy numbers A and B, it can be written that:

$$
\begin{gathered}
\mathrm{P}\left(n f(A)-\mathrm{y}_{\mathrm{i}} \& n f(B)>\mathrm{y}_{\mathrm{i}}\right)=\mathrm{P}\left(\operatorname{nf}(\mathrm{A})=\mathrm{y}_{\mathrm{i}}\right) \times \mathrm{P}\left(\operatorname{nf}(\mathrm{B})>\mathrm{y}_{\mathrm{i}}\right)=\mathrm{v}_{\mathrm{A}}\left(\mathrm{y}_{\mathrm{i}}\right)\left(1-\mathrm{P}\left(\operatorname{nf}(\mathrm{B}) \leq \mathrm{y}_{\mathrm{i}}\right)\right) \\
=\mathrm{v}_{\mathrm{A}}\left(\mathrm{y}_{\mathrm{i}}\right)\left(1-\mathrm{P}\left(\operatorname{nf}(\mathrm{B})<\mathrm{y}_{\mathrm{i}+1}\right)\right), \mathrm{i} \in 1, \ldots, \mathrm{n}-1
\end{gathered}
$$

Then,

$$
\mu_{<}(A, B)=\sum_{i=1}^{n-1}\left(v_{A}\left(y_{i}\right)\left(1-\omega_{B}\left(y_{i+1}\right)\right)\right)
$$

where 
$v_{A}(y)$ - probability that $y$ is used as the crisp value of the fuzzy number A $\omega_{B}(y)$ - probability that $z$ used as the crisp number of the fuzzy number B is lower than $y$. These values can be calculated with the use of the following formulas (2.6-2.8):

$$
\omega_{\mathrm{B}}(\mathrm{y})=\sum_{\mathrm{z} \in \mathrm{S}_{\mathrm{B}}, \mathrm{z}<y} \mathrm{p}_{\mathrm{B}}(\mathrm{y})
$$

$$
\mathrm{p}_{\mathrm{B}}(\mathrm{y})=\mu_{\mathrm{B}}(\mathrm{y})\left(\sum_{\mathrm{y} \in \mathrm{S}_{\mathrm{B}}} \mu_{\mathrm{B}}(\mathrm{y})\right)^{-1}
$$

$$
\mathrm{v}_{\mathrm{A}}(\mathrm{y})=\mu_{\mathrm{A}}(\mathrm{y})\left(\sum_{\mathrm{y} \in \mathrm{S}_{\mathrm{A}}} \mu_{\mathrm{A}}(\mathrm{y})\right)^{-1}
$$

where

$\mu_{A}(y)$ - the membership function of the fuzzy number A

$\mu_{B}(y)-$ the membership function of the fuzzy number B.

The function $\mu_{\geq}$is determined as in the formula (2.9):

(2.9)

$$
\mu_{\geq}\left(K\left(x_{i}\right), K\left(x_{j}\right)\right)=\bigcup_{r \in(1, \ldots, m)} \mu_{\geq}^{r}\left(x_{i}, x_{j}\right)
$$

where $\mathrm{U}$ is the generalizing operator for all $r$ criteria. Considering the fact of conformity between the alternatives and their evaluations, the fuzzy preference relation (with the domain of the set of alternatives) can be determined as membership function shown in formula (2.10):

$$
\mu_{\geq}^{\mathrm{F}}: A \times A \rightarrow[0,1] .
$$

The value of this function can be calculated with the following formula (2.11): 


$$
\mu_{\geq}^{\mathrm{F}}\left(a_{i}, a_{j}\right)=\mu_{\geq}\left(K\left(x_{i}, x_{j}\right)\right)
$$

It is to emphasize, that in case of crisp numbers (not fuzzy) of criteria vector, the relationships are shown as in formula (2.12):

$$
\begin{aligned}
& K\left(a_{i}\right) \geq K\left(a_{j}\right) \Leftrightarrow(\forall r \in(1, \ldots, m))\left(K_{r}\left(x_{i}\right) \geq K\left(x_{j}\right)\right) ; \\
& a_{i} \geq a_{j} \Leftrightarrow K\left(a_{i}\right) \geq K\left(a_{j}\right)
\end{aligned}
$$

The expression $\mu_{\geq}^{\mathrm{F}}$ allows for the creation of the matrix of the pairwise comparisons for the alternatives, according to the preferences $\mathrm{F}=\left\|\mu_{i j}\right\|_{n \times n}$, where $\mu_{i j}=\mu_{\geq}^{\mathrm{F}}\left(a_{i}, a_{j}\right)$. Based on the matrix of the pairwise comparisons, the ranking (the rank assigning) of the alternatives is possible.

The procedure for the aforementioned method can be described as follows:

1. Calculating the value of the membership function of the fuzzy relation type „lower" $\mu_{<}$for each pair of comparing alternatives, for each from $r$ criteria $\mu_{<}\left(K_{r}\left(x_{i}\right), K_{r}\left(x_{j}\right)\right)$.

2. Calculating the values of the membership functions of the fuzzy relation type „equal-orhigher" $\mu_{\geq}$for each alternative.

3. Calculating the level of preference for each alternative through aggregation of the values of the individual membership functions according to assumed criteria, taking into account the structure of the preferences (e.g. by consideration of weights).

4. Ordering of preferred alternatives.

5. Solution of the net model considering the preferred path.

The procedure is shown on the fig. 2 


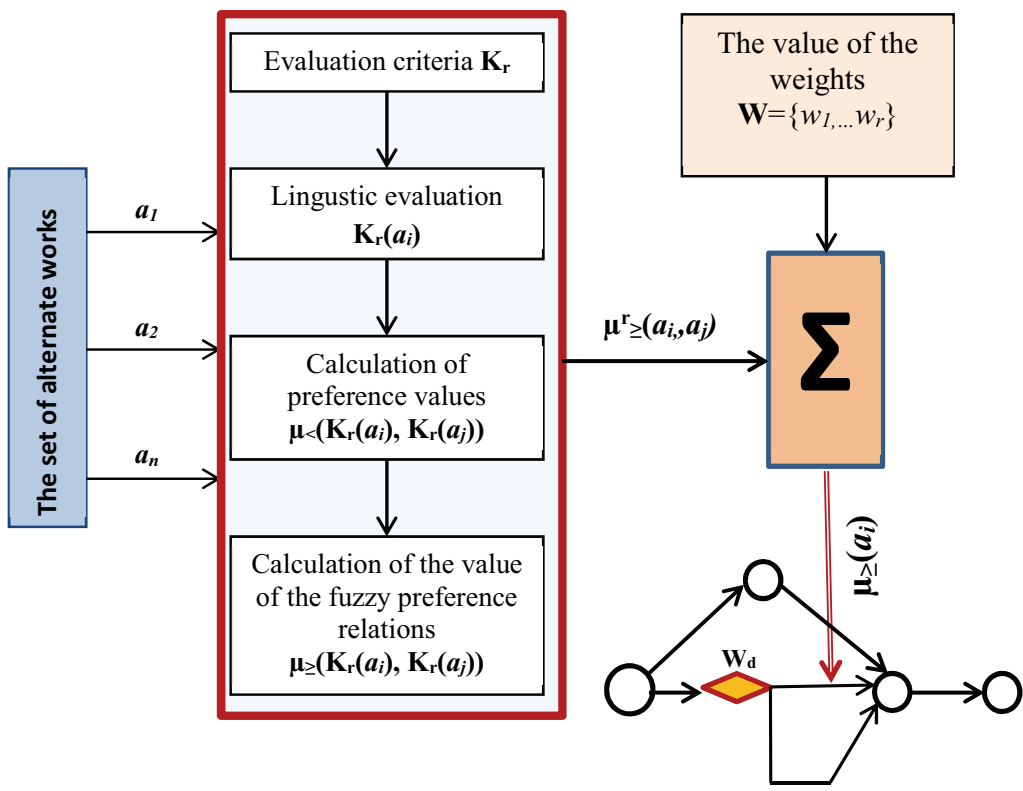

Fig. 2. The procedure of calculations in proposed model - the conceptual scheme

\section{THE EXAMPLE OF APPLYING THE PROPOSED METHOD}

Let's analyze the net model with the fuzzy decision node shown in fig 1 . The analysis will be limited to only one decision node $\mathrm{W}_{\mathrm{d} 2}$. The decision node $\mathrm{W}_{\mathrm{d} 2}$ is followed by two alternatives - two ways of executing the work $\mathrm{C}$ and C'. They can be marked as' $a_{1}, a_{2}$ respectively. Then the set of alternatives can be described as $A=\left\{a_{1}, a_{2}\right\}$. Let $K=\left\{K_{1}, K_{2}, K_{3}\right\}$ be the vector of evaluating criteria. It is assumed the criteria $K_{r}$ are as follows: the cost of the work execution, the time necessary to the work execution and the technological complexity of a given work.

The alternative with the highest preference factor $K\left(a_{i}\right)=\max _{i} \sum_{r} w_{r} \mu_{\geq}^{\mathrm{r}}\left(x_{i}, x_{j}\right)$ is to find. $W=$ $\left\{w_{1}, w_{2}, w_{3}\right\}$, is the vector of the weights characterizing the importance of assumed criteria (from the planner point of view - the decision maker). It is assumed that the fuzzy evaluations of every variant of works are modelled by linguistic variables, with consideration of the kinds of criteria. Then, they are transformed to the quantitative scale $Y=\{1,2, \ldots 10\}$ (itis universal set, based on that the fuzzy 
numbers are defined), in the way, that independently from the kind of the criterion, every time 1 is assigned to the poorest evaluation and 10 to the best one (see fig. 3). For the purposes of the example 4 possible linguistic evaluations were assumed: \{low (L), moderate (M), high (H), very high $(\mathrm{VH})\}$.

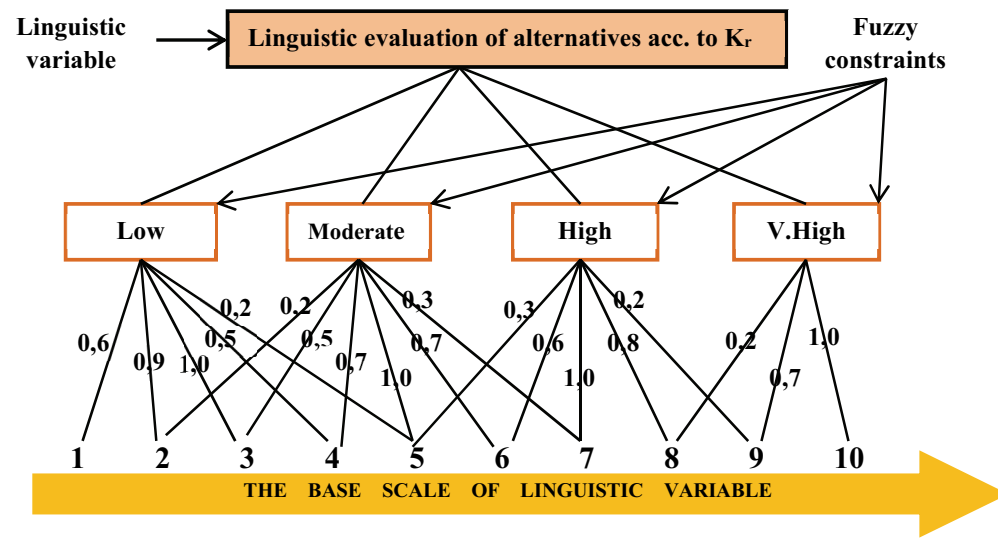

Fig. 3. The conceptual model of the fuzzy linguistic evaluation of alternatives

Every linguistic variable of evaluation is modelled through the fuzzy numbers with the certain membership function: $L=\left\{\frac{0,6}{1}+\frac{0,9}{2}+\frac{1}{3}+\frac{0,5}{4}+\frac{0,2}{5}\right\} ; \quad M=\left\{\frac{0,2}{2}+\frac{0,5}{3}+\frac{0,7}{4}+\frac{1}{5}+\frac{0,7}{6}+\frac{0,3}{7}\right\} ; \quad H=$ $\left\{\frac{0,3}{5}+\frac{0,6}{6}+\frac{1}{7}+\frac{0,8}{8}+\frac{0,2}{9}\right\} ; V H=\left\{\frac{0,2}{8}+\frac{0,7}{9}+\frac{1}{10}\right\}$.

The fuzzy evaluation of alternate variants of works $a_{i}$ can be shown as a matrix (3.1):

$$
K=\begin{array}{cccc} 
& K_{1} & K_{2} & K_{3} \\
a_{1} & H & L & V H \\
a_{2} & M & M & H
\end{array}
$$

For the example purposes the preferences of the planner were assumed in the form of the vector of the weights $\mathrm{W}=\{0,4 ; 0,3 ; 0,3\}$.

Calculation of the value of the membership functions $\mu_{<}\left(K_{r}\left(a_{1}\right), K_{r}\left(a_{2}\right)\right)$ is shown in the formula (3.2):

$$
\mu_{<}\left(K_{r}\left(a_{1}\right), K_{r}\left(a_{2}\right)\right)=\sum_{s=1}^{n} p_{K_{r}\left(a_{1}\right)}\left(y_{s}\right)\left(1-\sum_{j=1}^{s} p_{K_{r}\left(a_{2}\right)}\left(y_{j}\right)\right)
$$

Referring to the formula for the probability of different alternatives (2.8) we get:

$$
\mu_{<}\left(K_{r}\left(a_{1}\right), K_{r}\left(a_{2}\right)\right)=\sum_{s=1}^{n} p_{K_{r}\left(a_{1}\right)}\left(y_{s}\right)\left(1-\sum_{j=1}^{s} p_{K_{r}\left(a_{2}\right)}\left(y_{j}\right)\right)
$$




$$
p_{K_{r}\left(a_{i}\right)}\left(y_{S}\right)=\frac{\mu_{K_{r}\left(a_{i}\right)}\left(y_{s}\right)}{\sum_{y \in S_{K_{r}\left(a_{i}\right)}} \mu_{K_{r}\left(a_{i}\right)}(y)}
$$

where $r=1, \ldots, 4 ; i=1,2$.

Each alternative $a_{i}$ corresponds to the eveluation, made basing on individual criteria $\mathrm{K}_{\mathrm{r}}$ belonging to the sets $\{\mathrm{L}, \mathrm{M}, \mathrm{H}, \mathrm{VH}\}$ (see the formula (3.1)); for exaample $K_{1}\left(a_{1}\right)=H, K_{1}\left(a_{2}\right)=M$ etc. Each evaluation corresponds to the fuzzy number with its own memebership function as $\mu_{K_{1}\left(a_{1}\right)}\left(y_{1}\right)=0,3$; $\mu_{K_{1}\left(a_{1}\right)}\left(y_{2}\right)=0,6 ; \mu_{K_{1}\left(a_{1}\right)}\left(y_{3}\right)=1$ etc.

Considering that, the sum of evaluations for each alternative is equal respectively:

$$
\begin{aligned}
& \sum_{y \in S_{K_{1}\left(a_{1}\right)}} \mu_{K_{1}\left(a_{1}\right)}(y)=0,3+0,6+1,0+0,8+0,2=2,9 \\
& \sum_{y \in S_{\mathrm{K}_{1}\left(\mathrm{a}_{2}\right)}} \mu_{\mathrm{K}_{1}\left(\mathrm{a}_{2}\right)}(y)=0,2+0,5+0,7+1,0+0,7=3,4 \\
& \sum_{y \in S_{K_{2}\left(a_{1}\right)}} \mu_{K_{2}\left(a_{1}\right)}(y)=0,6+0,9+1,0+0,5+0,2=3,2 \\
& \sum_{y \in S_{K_{2}\left(a_{2}\right)}} \mu_{K_{2}\left(a_{2}\right)}(y)=0,2+0,5+0,7+1,0+0,7=3,4 \\
& \sum_{y \in S_{K_{3}\left(a_{1}\right)}} \mu_{K_{3}\left(a_{1}\right)}(y)=0,2+0,7+1,0=1,9 \\
& \sum_{y \in S_{K_{3}\left(a_{2}\right)}} \mu_{K_{3}\left(a_{2}\right)}(y)=0,3+0,6+1,0+0,8+0,2=2,9
\end{aligned}
$$

Then:

$$
\begin{aligned}
\mu_{<}\left(K_{1}\left(a_{1}\right), K_{1}\left(a_{2}\right)\right) & =\mu_{<}(H, M) \\
= & \frac{0,3}{2,9}\left(1-\frac{(0,2+0,5+0,7)}{3,4}\right)+\frac{0,6}{2,9}\left(1-\frac{(0,2+0,5+0,7+1)}{3,4}\right) \\
+ & \frac{1}{2,9}\left(1-\frac{(0,2+0,5+0,7+1+0,7)}{3,4}\right)=0,143
\end{aligned}
$$


(3.12)

$$
\begin{aligned}
\mu_{<}\left(K_{2}\left(a_{1}\right), K_{2}\left(a_{2}\right)\right)=\mu_{<}(L, M) & \\
= & \frac{0,6}{3,2}(1-0)+\frac{0,9}{3,2}(1-0)+\frac{1}{3,2}\left(1-\frac{(0,2)}{3,4}\right)+\frac{0,5}{3,2}\left(1-\frac{(0,2+0,5)}{3,4}\right) \\
& +\frac{0,2}{3,2}\left(1-\frac{(0,2+0,5+0,7)}{3,4}\right)=0,925
\end{aligned}
$$

$$
\begin{aligned}
& \mu_{<}\left(K_{3}\left(a_{1}\right), K_{3}\left(a_{2}\right)\right)=\mu_{<}(V H, H) \\
& =\frac{0,2}{1,9}\left(1-\frac{(0,3+0,6+1)}{2,9}\right)+\frac{0,7}{1,9}\left(1-\frac{(0,3+0,6+1+0,8)}{2,9}\right)=0,062
\end{aligned}
$$

Calculation of the fuzzy relation $\mu_{\geq}\left(K_{r}\left(a_{1}\right), K_{r}\left(a_{2}\right)\right)$ can be done with the use of the formula (3.14):

$$
\mu_{\geq}\left(K_{r}\left(a_{1}\right), K_{r}\left(a_{2}\right)\right)=1-\mu_{<}\left(K_{r}\left(a_{1}\right), K_{r}\left(a_{2}\right)\right)
$$

The respective values are as follows:

$$
\begin{aligned}
& \mu_{\geq}\left(K_{1}\left(a_{1}\right), K_{1}\left(a_{2}\right)\right)=1-\mu_{<}\left(K_{1}\left(a_{1}\right), K_{1}\left(a_{2}\right)\right)=1-0,143=0,857 \\
& \mu_{\geq}\left(K_{2}\left(a_{1}\right), K_{2}\left(a_{2}\right)\right)=1-\mu_{<}\left(K_{2}\left(a_{1}\right), K_{2}\left(a_{2}\right)\right)=1-0,925=0,075 \\
& \mu_{\geq}\left(K_{3}\left(a_{1}\right), K_{3}\left(a_{2}\right)\right)=1-\mu_{<}\left(K_{3}\left(a_{1}\right), K_{3}\left(a_{2}\right)\right)=1-0,062=0,938
\end{aligned}
$$

Calculation of the preference level of the alternative $a_{1}$ in comparison to the alternative $a_{2}$ where the weights are considered can be done with use of the formula (3.18):

$$
\mu_{\geq}\left(a_{1}, a_{2}\right)=\sum_{r} w_{r} \mu_{\geq}^{r}\left(a_{1}, a_{2}\right)=0,4 \times 0,857+0,3 \times 0,075+0,3 \times 0,938=0,647
$$

The preference level $\mu_{\geq}\left(a_{1}\right)$ for the alternative $a_{1}$ is equal to 0,647 .

Similar calculations can be done for the $a_{2}$ alternative. 
Calculation of the value of the membership function $\mu_{<}\left(K_{r}\left(a_{2}\right), K_{r}\left(a_{1}\right)\right)$ for respective evaluation criteria can be proceeded as follows:

$$
\begin{aligned}
\mu_{<}\left(K_{1}\left(a_{2}\right), K_{1}\left(a_{1}\right)\right)=\mu_{<}(M, H) & \\
= & \frac{0,2}{3,4}(1-0)+\frac{0,5}{3,4}(1-0)+\frac{0,7}{3,4}(1-0)+\frac{1}{3,4}(1-0)+\frac{0,7}{3,4}\left(1-\frac{0,3}{2,9}\right) \\
+ & \frac{0,3}{3,4}\left(1-\frac{(0,3+0,6)}{2,9}\right)=0,952
\end{aligned}
$$

$$
\begin{aligned}
\mu_{<}\left(K_{2}\left(a_{2}\right), K_{2}\left(a_{1}\right)\right)=\mu_{<}(M, L) & \\
= & \frac{0,2}{3,4}\left(1-\frac{0,6}{3,2}\right)+\frac{0,5}{3,4}\left(1-\frac{0,6+0,9}{3,2}\right)+\frac{0,7}{3,4}\left(1-\frac{0,6+0,9+1}{3,2}\right) \\
& +\frac{1}{3,4}\left(1-\frac{0,6+0,9+1+0,5}{3,2}\right)=0,191
\end{aligned}
$$

$$
\begin{aligned}
\mu_{<}\left(K_{3}\left(a_{2}\right), K_{3}\left(a_{1}\right)\right)=\mu_{<}(H, V H) & \\
= & \frac{0,3}{2,9}(1-0)+\frac{0,6}{2,9}(1-0)+\frac{1}{2,9}(1-0)+\frac{0,8}{2,9}(1-0)+\frac{0,2}{2,9}\left(1-\frac{0,2}{1,9}\right) \\
& +\frac{0,3}{3,1}\left(1-\frac{(0,3+0,6)}{2,9}\right)=0,993
\end{aligned}
$$

Calculation of the fuzzy relation $\mu_{\geq}\left(K_{r}\left(a_{2}\right), K_{r}\left(a_{1}\right)\right)$ :

$$
\begin{aligned}
& \mu_{\geq}\left(K_{1}\left(a_{2}\right), K_{1}\left(a_{1}\right)\right)=1-\mu_{<}\left(K_{1}\left(a_{2}\right), K_{1}\left(a_{1}\right)\right)=1-0,952=0,048 \\
& \mu_{\geq}\left(K_{2}\left(a_{2}\right), K_{2}\left(a_{1}\right)\right)=1-\mu_{<}\left(K_{2}\left(a_{2}\right), K_{2}\left(a_{1}\right)\right)=1-0,191=0,809 \\
& \mu_{\geq}\left(K_{3}\left(a_{2}\right), K_{3}\left(a_{1}\right)\right)=1-\mu_{<}\left(K_{3}\left(a_{2}\right), K_{3}\left(a_{1}\right)\right)=1-0,993=0,007
\end{aligned}
$$

Calculation of the preference level for $a_{2}$ alternative, compared to the $a_{1}$ alternative, is executed with the use of weights, by the formula (3.24):

$$
\mu_{\geq}\left(a_{2}, a_{1}\right)=\sum_{r} w_{r} \mu_{\geq}^{r}\left(a_{2}, a_{1}\right)=0,4 \times 0,048+0,3 \times 0,809+0,3 \times 0,007=0,264
$$


The level of preference $\mu_{\geq}\left(a_{2}\right)$ of $a_{2}$ alternative is equal to 0,264 .

Comparing the levels of preferences of these two alternatives, it can be observed that alternative $a_{1}$ is better (preferred more) than $a_{2}$ alternative, because $\mu_{\geq}\left(a_{1}\right)>\mu_{\geq}\left(a_{2}\right)$. Having the preferences calculated and the choices made (alternative $a_{1}$ in the example, marked as $\mathrm{C}$ in fig. 1), the net model analysis can be proceeded then in the traditional, well known methods (which are omitted in the article).

\section{CONCLUSIONS}

The proposed by the author alternative net model with the fuzzy decision node allow for analyzing the case where alternate ways of work execution are modelled. This approach make the analysis of some variants possible based on one net model. The variants can vary with more than one feature. Usually some of the features are really important (e.g. the cost, the time, the complexity of works). The choice of the variant (made in the fuzzy decision node) simplifies the net model to the plain one, which can be analyzed in a traditional way. The decision making in the fuzzy decision node is based on fuzzy relations and the calculation taken from probability theory. The proposed calculation procedure is not complicated and allow - in a quick way - to model the important parameters of a given work through fuzzy numbers and linguistic variables. Moreover, the decision node allow for the consideration of quantitative factors and qualitative factors too. The proposed alternative net model with the fuzzy decision node allows for overall analysis, considering uncertainty of the input data in a simple way. The example calculated proves that the best variant of works can be chosen quickly based on assumed criteria. It allows for creating ascending series of preferred variants that gives addition information in a form of the preference levels (of alternate ways of works execution). Combining the decision model (in a form of a fuzzy decision node) with the net model can be helpful in strategic planning as well as for operational planning of construction projects. The fuzzy decision nodes can be placed in deterministic net model as well as in stochastic and fuzzy net models. The core of the issue comes down to choosing the variant of work in the net model with highest level of preference, calculated based on the most important parameters in a given circumstances. Next, the ned model (after the decision node) can be calculated traditionally, according to the rules relevant to the kind of the net model assumed. 


\section{REFERENCES}

1. H. Anysz, N.Ibadov, "Neuro-fuzzy predictions of construction site completion dates", Technical Transactions 6/2017, pp. 51-58, DOI: 10.4467/2353737XCT.17.086.6562

2. H. Anysz, A. Zbiciak, „Przyczyny powstawania opóźnień w realizacji kontraktów budowlanych-analiza wstępnych wyników badania ankietowego", Autobusy - Technika, Eksploatacja, Systemy Transportowe 3/2013, pp 1-10

3. A.N. Borisov, O.A. Krumberg, I.P. Federov "Decision making based on fuzzy models: Examples", Riga, Zinatne Publ., 1990 (in Russian).

4. V. Chernov, O. Dorokhov, L. Malyaretz, "Construction of Estimates in the Choice of Alternative Solutions by Using the Fuzzy Utilities", Transport and Telecommunication, Volume 13, Issue 1, Pages 11-17, DOI: https://doi.org/10.2478/v10244-012-0002-z.

5. N. Ibadov, "Contractor selection for construction project, with the use of fuzzy preference relation", XXIV R-S-P seminar, Theoretical Foundation of Civil Engineering, Published by Elsevier Ltd. Procedia Engineering 111 ( 2015 ) pp. $317-323$.

6. N. Ibadov, "Determination of the risk factors impact on the construction projects implementation using fuzzy sets theory", Acta Physica Polonica A 130 (2016), No. 1, pp. 107-111, DOI: 10.12693/APhysPolA.130.107

7. N. Ibadov, "Fuzzy estimation of activities duration in construction projects", Archives of Civil Engineering. Vol. LXI, ISSUE 2/2015, pp. 23-34.

8. N. Ibadov, "Selection of Construction Project Taking into Account Technological and Organizational Risk", Acta Physica Polonica A 132 (2017), No. 3-II, pp. 974-977, DOI:10.12693/APhysPolA.132.974

9. N. Ibadov, "Wielokryterialny wybór wariantów wykonania przedsięwzięć budowlanych na podstawie rozmytej relacji preferencji”. Logistyka 6/2014, Pełny tekst na CD3 str. 4564-4569.

10. N. Ibadov, "Wybór dostawcy w przedsięwzięciach budowlanych na podstawie rozmytej relacji preferencji", Logistyka 3/2015, Pełny tekst na CD1 str. 1823-1829.

11. N. Ibadov, J. Rosłon, „Technology Selection For Construction Project, With The Use Of Fuzzy Preference Relation", Archives of Civil Engineering Volume 61, Issue 3 (Sep 2015), pp. 105-118, DOI: https://doi.org/10.1515/ace-2015-0028

12. J. Konior, „,Random And Fuzzy Measure Of Unpredictable Construction Works”, Archives of Civil Engineering Volume 61, Issue 3 (Sep 2015), pp. 75-88, DOI: https://doi.org/10.1515/ace-2015-0026

13. M. Książek, P. Nowak, S. Kivrak, J. Rosłon, L. Ustinovichius, “Computer-aided decision-making in construction project development“", Journal of Civil Engineering and Management, 2015, vol. 21 (2), pages: 248-259, ISSN $1392-3730$.

14. J. Kulejewski, "Construction Project Scheduling With Imprecisely Defined Constraints", The CIB International Conference - MISBE 2011 " Management and Innovation for a Sustainable Built Environment", June 19-23., Amsterdam, The Netherlands, MISBE 2011 Proceedings pp. 1518-1533, ISBN: 9789052693958

15. J. Kulejewski, "Construction scheduling methods including fuzzy nature of the data" (in Polish). Dissertation. Warsaw University of Technology. Poland 2010

16. J. Kulejewski, "Planning of Construction Schedule with Flexible Constraints", 10th International Conference Modern Building Materials, Structures and Techniques, 2010, May 19-21, Vol.1 - Selected Papers, ed. P. Vainiunas and E. K. Zavadskas, Vilnius Gedyminas Technical University, pp. 442-445.

17. E. Plebankiewicz, M. Juszczyk, J. Malara, ,Szacowanie czasów realizacji zadań z wykorzystaniem metody PERT na przykładzie konkretnej realizacji”, Archives of Civil Engineering Volume 61, Issue 3 (Sep 2015), pp.51-62 , DOI: https://doi.org/10.1515/ace-2015-0024

18. E. Radziszewska-Zielina, "Fuzzy control of the partnering relations of a construction enterprise" Journal of Civil Engineering and Management, 17(1), pp. 5-15, 2011.

19. E. Radziszewska-Zielina, B. Szewczyk, "Controlling Partnering Relations In Construction Operations Using Fuzzy Reasoning”, Archives of Civil Engineering Volume 61, Issue 3 (Sep 2015), pp. 89-104, DOI: https://doi.org/10.1515/ace-2015-0027.

20. E. Radziszewska-Zielina, G. Śladowski, "Supporting the Selection of a Variant of the Adaptation of a Historical Building with the Use of Fuzzy Modelling and Structural Analysis", Journal of Cultural Heritage, Vol. 26, JulyAugust 2017, pp. 53-63, https://doi.org/10.1016/j.culher.2017.02.008

21. E. Radziszewska-Zielina, G. Śladowski, M. Sibielak, "Planning the reconstruction of a historic building by using a fuzzy stochastic network", Automation in Construction, Vol. 84, 2017, pp. 242-257, https://doi.org/10.1016/j.autcon.2017.08.003 
22. L. O. Uğur, U. N. Baykan, "An Invistigation About The Fuzzy Logic Aplications In Construction Managemen", Düzce University Journal of Science \& Technology, 4(2016), pp. 207-226.

23. L. O. Uğur, U. N. Baykan, "Fuzzy Sets Applications in Civil Engineering Basic Areas”, Düzce University Journal of Science \& Technology, 4(2016), pp. 176-206

24. L. Ustinovichius, et al., "Verbal analysis of risk elements in construction contracts. In: International Conference on Cooperative Design, Visualization and Engineering. Springer, Berlin, Heidelberg, 2006. p. 295-302.

25. L. A. Zadeh, "A computational approach to fuzzy quantizers in natural languages", Computing and Mathematics with Applications 9, 149-184, 1983,

26. L. A. Zadeh, "Fuzzy Sets”, Information and Control, 1965, vol. 8. pp. 338-353.

27. Q. Zhao, L. Zeng, J. Liu, "Fuzzy Integral Multiple Criteria Decision Making Method Based on Fuzzy Preference Relation on Alternatives", Journal of Systems Science and Information, Volume 4, Issue 3, pp. 280-290, DOI: https://doi.org/10.21078/JSSI-2016-280-11.

\section{LIST OF FIGURES:}

Fig. 1. The concept of a net model: a) AOA model; b) AOA model with the fuzzy decision nodes

Rys. 1. Konceptualny model sieciowy: a) dwupunktowy model sieciowy; b) dwupunktowy model sieciowy z rozmytymi węzłami decyzyjnym

Fig. 2. The procedure of calculations in proposed model - the conceptual scheme

Rys. 2. Konceptualny model procedury obliczenia według proponowanej metody

Fig. 3. The conceptual model of the fuzzy linguistic evaluation of alternatives

Rys. 3. Konceptualny model rozmytej oceny lingwistyczniej alternatywnych robót 


\section{PlanOWANIE PRZEDSIĘWZIĘĆ BUDOWLANYCH ZA POMOCĄ ALTERNATYWNEGO MODELU SIECIOWEGO Z ROZMYTYM WEZZLEM DECYZYJNYM}

Słowa kluczowe: planowanie przedsięwzięć budowlanych, rozmyty węzeł decyzyjny, analiza sieciowa, zmienne lingwistyczne, liczby rozmyte, rozmyta relacja preferencji

\section{STRESZCZENIE:}

W praktyce budowlanej, na etapie planowania realizacji przedsięwzięcia budowlanego, planiści starają się brać pod uwagę możliwość występowania w trakcie realizacji projektu niekorzystnych sytuacji i ich konsekwencji. Wobec powyższego trzeba w decyzjach planistycznych zastosować odpowiednie narzędzia do modelowania niepewności, jak również rozważać alternatywne warianty realizacji całego przedsięwzięcia lub najbardziej newralgicznych (krytycznych) robót w przedsięwzięciu i dokonać prawidłowego wyboru ze zbioru alternatywnych wariantów, uwzględniając kryteria oceny zależne od istotnych cech danego przedsięwzięcia w danej sytuacji decyzyjnej (warunkach realizacji). Rezultatem procesów planowania są harmonogramy i modele sieciowe. Należy podkreślić, że zastosowanie obecnie tradycyjnych modeli sieciowych (np. CPM i PERT) w planowaniu złożonych przedsięwzięć, jakimi niewątpliwie są przedsięwzięcia budowlane, nie daje możliwości analizowania alternatywnych rozwiązań w zakresie technologii i organizacji wykonania wybranych lub wszystkich robót jakie należy realizować.

Uwzględniając fakt, że zarządzanie i planowanie przedsięwzięć budowlanych prowadzi się w warunkach niepewności niestochastycznej, autor proponuje stworzyć na bazie klasycznych modeli sieciowych alternatywny model z rozmytym węzłem decyzyjnym. Takie podejście pozwoli modelować czynności, względem siebie alternatywne. Wprowadzenie węzła decyzyjnego da planiście (podejmującemu decyzje) możliwość wyboru najwłaściwszego wariantu w danych okolicznościach (sytuacjach decyzyjnych) planowania i zarządzania. Alternatywny model sieciowy z rozmytym węzłem decyzyjnym jest acyklicznym multigrafem, w którym niektóre, wybrane węzły (zdarzenia) są ze sobą powiązane wielokrotnymi (multi) strzałkami, które odpowiadają poszczególnym alternatywom wykonania robót. Poziom preferencji opisany przez wskaźniki (wartości) funkcji przynależności zmiennych lingwistycznych (lub zbioru rozmytego) w stosunku do istotnych charakterystyk przedsięwzięcia, określa się na podstawie rozmytego modelu decyzyjnego w węźle decyzyjnym.

W skutek oceny alternatyw, każda alternatywna czynność uzyskuje stopień (wskaźnik) preferencji danego sposobu wykonania roboty w postaci wartości funkcji przynależności „większe-równe” $\mu_{\geq}$. Najbardziej preferowaną alternatywą, w określonej sytuacji decyzyjnej, będzie robota z najwyższym wskaźnikiem preferencji. Niech $G=\left(X, A, S, W_{d}\right)$ będzie acyklicznym multigrafem jako alternatywnym modelem sieciowym, który posiada $X=\{1,2, \ldots, k\}$ zbiór wierzchołków - zwanych w modelu sieciowym zdarzeniami; zbiór zorientowanych łuków modelujących wszystkie alternatywne warianty robót $A=\left\{a_{1}, \ldots, a_{i}, \ldots, a_{n}\right\}$; zbiór zorientowanych łuków modelujących wszystkie pojedyncze roboty $S=$ $\left\{s_{1}, \ldots, s_{i}, \ldots, s_{u}\right\}$ oraz zbiór węzłów decyzyjnych $W_{d}=\{1,2, \ldots m\}$ pozwalających - na podstawie określonego modelu decyzyjnego - na dokonanie wyboru najbardziej preferowanego wariantu robót. Należy podkreślić, że jeżeli istnieje tylko jeden wariant wykonania roboty, to węzeł decyzyjny zostaje skasowany. Poziom preferencji $\mu_{\geq}(i, j) \in[0,1]$ roboty $(i, j) \mathrm{w} r$ alternatywach ustala się za pomocą kryteriów oceny, określających preferencję danego sposobu wykonania roboty. Pojawienie się węzła decyzyjnego zapowiada pojawienie się zbioru możliwych dróg alternatywnych. Po wyborze najbardziej preferowanej drogi, dalsze obliczenia sieci prowadzi się w tradycyjny sposób (na przykład tak jak w metodzie CPM). Istotnym elementem metodologicznym jest rozmyta ocena rozpatrywanych alternatyw za pomocą zmiennej 
lingwistycznej, mogącej przyjmować wartości „lepsze”, ,gorsze”, „duży”, „mały” i itp. Podstawę matematyczną wyboru spośród alternatywnych sposobów wykonania robót w modelu sieciowym, stanowi rozmyta relacji porządku na podstawie lingwistycznych ocen wraz z metodami obliczeniowymi stosowanymi w teorii prawdopodobieństwa. Relację rozmytego porządku dla rozmytych ocen A i B określa się poprzez probabilistyczne oceny dla ich ostrych (nierozmytych) ekwiwalentów i oblicza się za pomocą wzoru: $\mu_{\geq}(\mathrm{A}, \mathrm{B})=1-\mu_{<}(\mathrm{A}, \mathrm{B})$. Procedura postępowania w powyższej metodzie jest następująca:

1. Obliczanie wartości funkcji przynależności relacji rozmytej typu „mniejsze” $\mu_{<}$dla każdej pary porównywanych alternatyw dla każdego r-tego kryterium $\mu_{<}\left(K_{r}\left(x_{i}\right), K_{r}\left(x_{j}\right)\right)$.

2. Obliczanie odpowiednich wartości funkcji przynależności relacji typu „większe-równe” $\mu_{\geq}$dla każdej alternatywy.

3. Obliczanie stopnia preferencji dla każdej alternatywy poprzez agregację wartości funkcji przynależności według kryteriów z uwzględnieniem określonej struktury preferencji (na przykład poprzez uwzględnienie współczynników wagowych)

4. Tworzenie szeregu preferencyjnego porównanych alternatyw.

5. Rozwiązania modelu sieciowego według ścieżki preferowanej.

Proponowana procedura obliczeniowa jest prosta i pozwala szybko modelować istotne parametry roboty poprzez liczby rozmyte i zmienne lingwistyczne. Ponadto, węzeł decyzyjny pozwała uwzględniać zarówno parametry ilościowe jak i parametry jakościowe. Proponowany alternatywny model sieciowy z rozmytym węzłem decyzyjnym daje możliwość prowadzenia kompleksowej analizy z możliwością uwzględnienia i modelowania niepewności danych wejściowych w łatwy sposób. Przedstawiony przykład obliczeniowy wykazuje możliwość szybkiego wyboru najlepszego wariantu na podstawie przyjętych kryteriów oceny i pozwała szeregować warianty robót, co daje dodatkową informacje w czynnościach alternatywnych modelu sieciowego w postaci stopnia preferencji. Połączenie modelu decyzyjnego w postaci węzła decyzyjnego z modelem sieciowym może być przydatne zarówno w strategicznym jak i taktycznym planowaniu realizacji przedsięwzięć budowlanych. Aplikacji węzła decyzyjnego można dokonać zarówno w sieciach deterministycznych, stochastycznych, jak i rozmytych. Problem sprowadza się zatem do wyboru z zestawu alternatywnych wariantów robót $\mathrm{w}$ modelu sieciowym robotę o wyższym stopniu preferencji według najistotniejszych parametrów w danej sytuacji a dalszą część (za węzłem decyzyjnym) oblicza się tradycyjne zgodnie z rodzajem sieci. 